John Carroll University

Carroll Collected

Psychology

Psychology

2009

\title{
The shaping of a saint-president: Latent clues from Nelson Mandela's autobiography
}

Abdulrazaq Imam

John Carroll University, aimam@jcu.edu

Follow this and additional works at: http://collected.jcu.edu/psyc-facpub

Part of the Other Psychology Commons

\section{Recommended Citation}

Imam, Abdulrazaq, "The shaping of a saint-president: Latent clues from Nelson Mandela's autobiography" (2009). Psychology. 7. http://collected.jcu.edu/psyc-facpub/7

This Article is brought to you for free and open access by the Psychology at Carroll Collected. It has been accepted for inclusion in Psychology by an authorized administrator of Carroll Collected. For more information, please contact connell@jcu.edu. 


\section{The Shaping of a Saint-President: Latent Clues from Nelson Mandela's Autobiography}

Abdulrazaq A. Imam

John Carroll University

Keywords: shaping, political behavior, autonomous man, autobiography, Nelson Mandela

Abstract: Nelson Mandela's Long Walk to Freedom provides evidence organized in the form of antecedent-behavior-consequence units, which suggest that a shaping process effected during his many years of incarceration best describes the origins of the outcome represented by the political order in South Africa following his release. The analysis shows that Mandela's radicalism at the start of his imprisonment on Robben Island changed into a saintly presidential aura in the end, through a systematic selection process that actively involved Mandela himself and his political aspirations. The saintly qualities ascribed to Mandela after his release by many around the world are consistent with Skinner's (1971) views on autonomous man.

To many around the world, the current political dispensation in South Africa represents the triumph of the black struggle spearheaded by Nelson Mandela and his colleagues and aided by international sanctions against the hateful apartheid system it replaced. A reading of Mandela's own account of events tends to validate this view generally. Mandela's autobiography suggests, however, certain undercurrents that significantly influenced the final outcome. It appears two important forces collided to yield the current modus vivendi that South Africa represents: namely, the undeclared political aspirations of Nelson Mandela and some of his colleagues, and the authorities' covert work on the ANC leadership in captivity, particularly Nelson Mandela himself. What appears fortuitous many times may have been force majeure - apparently unavoidable circumstances that occurred due to the dictates of the apartheid authorities, especially during the later years in the Robben Island and Pollsmoor Prisons. Some of these will be highlighted in what follow, prima facie. The veracity of the conclusions reached

Address correspondence to: Dr. A. A. Imam, Department of Psychology, John Carroll University, 20700 North Park Blvd, University Heights, OH 44118. Dedicated to the fond memory of my beloved Aminat Alaaya-Imam. 
here may rest, in part, on the accounts rendered by the other actors in the drama represented by Mandela's journey (e.g., see Sparks, 1994). Mandela's (1994) Long Walk to Freedom is a rich source of material for those interested in verbal and rule-governed behavior, verbal self-report as data (e.g., Ericsson \& Simon, 1980), control techniques for the management of behavior especially in corrections (e.g., Cohen \& Filipczak, 1989; Ellis, 1992), say-do and do-say correspondences (e.g., Baer, Detrich, \& Weninger, 1988; Ward \& Stare, 1990), memory (e.g., Neisser, 1982) and remembering (e.g., Neisser \& Fivush, 1994), and so on. A major focus in the present paper is the shaping processes in what Mandela's autobiography reveals. Autobiographical reports are valuable psychological data (Barlow, 1981; see also Neisser, 1994) and may be quite useful for the study of political behavior (c.f., Hermann, 1986) and the nexus this may share with incarceration and reform of dissidents in prisons across the globe.

The shaping procedure in the laboratory may be so simple and basic to operant psychology that we are liable to neglect its significance in the control of behavior. Outside the laboratory, the dynamics of control of behavior can be intricate and fascinating. As Skinner (1974) pointed out, institutions exercise awesome control over individual behavior, reinforcing their exertion by those who run them and engendering countercontrol by those at the receiving end. To say that operant psychology has much to offer society as we seek solutions to human problems is not a new claim. What is new is that more than thirty-five years since the publication of Beyond Freedom and Dignity, we have some new evidence for the kinds of control of human behavior B. F. Skinner talked about that raised so many eyebrows. The evidence in the Long Walk to Freedom is vast and compelling. In the absence of an official admission, it is not impossible to make a case beyond Mandela's own account to support the possibility of an actual program implemented for the protagonists who served with him in the various prisons he visited with his colleagues in the present case. Nevertheless, for the purposes of this paper, I will stay within Mandela's autobiographical text for direct evidence, for the most part, to illustrate the shaping processes involved. I think this is psychologically, and more specifically behaviorally, more interesting and challenging. Skinner's (1974) notions of control and countercontrol are quintessentially illustrated. Furthermore, as discussed further below, his (Skinner, 1971) double-edged ideas about autonomous man present separate but related issues of how individual action is credited traditionally and how a science of behavior appears to take that credit away. The aftermath of Mandela's release and rise to the South African presidency was characterized by a saintly ascription to him and his achievements. Whereas one could seek and find some hints in Mandela's account, clearly, much of such evidence would come from extra- 
autobiographical sources, beyond the contents of his memoir. To render an integrated behavior analytic perspective on Mandela's story requires that both his experiences under incarceration and after release get adequate consideration here.

Before I present the shaping analyses, however, it may be useful to present an overview of Mandela's account to provide some context in which to place the subsequent analyses. Given the emphases on Mandela's text and the extent and depth of the participation of various individuals, organizations, institutions, and government entities involved in his narrative, it seems only appropriate to offer a glimpse of the chronological content and structure rendered by his account in what comes next. A discussion of shaping and its relevance to Mandela's case then follows, with its ramifications for his saintly portrayal and the notion of an autonomous man.

\section{A Brief OVERVIEW OF MaNdela's AcCount}

Mandela's account of his life as a co-extension of the African National Congress (ANC) begins in earnest in Part 3 of Long Walk to Freedom, when Walter Sisulu introduced him to the organization. Covering the period from 1944 to early 1950s, it marked the formation of the Congress Youth League (CYL) in 1944 and the assumption of the Defiance Campaign of 1952, culminating in the arrest, trial, and conviction, with suspended 9-month sentences, of 21 leaders of the ANC, the South African Indian Congress (SAIC), and the CYL, including Mandela. Spanning the period between 1952 and 1956, Part 4 opens with the effective ascension of Mandela to the National Executive Committee (NEC) of the ANC at the end of 1952, followed by a series of banning orders imposed on him and others. These were busy times, witnessing the birth of the Mandela-Plan (or M-Plan) for the underground operation of the ANC in anticipation of government ban of the organization and the organization of the failed Sophiatown removal protests. Mandela opened his own law offices with Oliver Tambo and successfully defended his case with the Law Society of the Transvaal, which wanted to eliminate him from the roll of accredited attorneys. Mandela helped Walter Sisulu organize a trip to Bucharest and China without NEC approval, and offered a burgeoning rationale for armed struggle.

Part 5 describes the arrest and protracted treason trial of 156 individualsblacks, Indians, whites, and coloureds-lasting between December 1956 and March 1961, and ending with the Verdict of not guilty. In Part 6, Mandela went underground - practically from the court - and out to the rest of Africa where he generally received "royal" treatment. This trip occurred sometime between February and August 1962. Before the trip, Mandela argued for and obtained approval to begin an armed struggle, and was empowered to form a military wing 
of the ANC; hence, the birth of Umkhonto we Sizwe, or MK, with Nelson Mandela, Joe Slovo, and Walter Sisulu on its High Command. During his extensive tour of Africa, Mandela underwent military training in Ethiopia, effectively establishing his terrorist credentials.

Part 7 (August 1962 to June 12, 1964) takes us through the Rivonia trial for sabotage, which led to life sentences for most of the defendants, including Mandela, and their eventual incarceration on Robben Island. In Part 8, Mandela describes the agonizing indignities they suffered on Robben Island during the first five years of incarceration (covering 1964 to 1969) including hard labor, amidst nerve-racking prison routines, which they fought at every opportunity, suffering severe consequences as a result. Inhuman visiting hours and protocols, censorship of personal letters, race-based diets, and solitary confinement were among the many hardships they experienced on the Island.

Covering 1969 to 1982, Part 9 presents more relaxed prison conditions: phasing out manual labor altogether; introduction of religious services, concerts, films, drama; access to books and newspapers; attempts to woo Mandela to government's Bantu policies; and radio broadcasts by the prison authorities. Mandela, urged by Ahmed Kathrada and Walter Sisulu, started writing his memoirs; a large portion was discovered by the authorities and seized. Arrests during the Soweto Uprising brought younger, more militant activists to the Island, and Mandela and his colleagues encountered the next generation of freedom fighters. The part concluded with the move of only four of the old-timers, Mandela, Sisulu, Mlangeni, and Mhlaba, to Pollsmoor maximum-security prison in the Cape.

Life has so much changed and improved in Pollsmoor Prison in Part 10 that the reader might wonder, in many places, if Mandela was incarcerated still. It covers the period between 1982, on arriving at this "five-star (prison) hotel," and 1990, with arguments over the manner of Mandela's release in February. Talks about talks began here, initiated by Mandela who, by this time, had been separated from his colleagues brought to Pollsmoor with him; part of the separation took Mandela to another prison, Victor Verster (in 1988) where he lived in a cottage by himself, with an official cook at his service.

Part 11 witnesses the release of Mandela. He began his travels and meetings with world leaders amidst unexpected increase in violence around South Africa. Consultations began with the ANC in exile, and when unbanned, at home. There were negotiations about negotiations, and then the negotiations started. The death of Oliver Tambo marked Mandela's ascension to ANC presidency, the national elections were held, and of course, Nelson Mandela was inaugurated as president of South Africa. 
As noted in the foregoing, much of the memoirs in Long Walk to Freedom originated from Robben Island at the urging and behest of Ahmed Kathrada and Walter Sisulu when Mandela turned fifty-seven, intended for publication on his sixtieth birthday. Although originally meant "... to remind people of what we had fought and were still fighting for," (Mandela, 1994, p. 462; my emphases) the memoirs, upon their seizure, provided the authorities valuable information on the movement, its leadership, tactics and strategies, policies and values, and the tenacity and weaknesses of those who count most in the ANC. The value of the discovered manuscripts to the authorities cannot be overestimated for serving as a basis for conducting a systematic, covert work on the ANC leadership in captivity, including Nelson Mandela himself. A good part of such work would consist of molding their behavior toward a goal the apartheid authorities considered desirable. 'Mandela's own account of events strongly suggests that this may well have happened, systematically or otherwise-in the parlance of behavior analysis, shaping.

\section{Shaping ANd Other Related Procedures}

As old as the discovery of the operant by B. F. Skinner in the 1930s, shaping is a well-established procedure in behavior analysis (see Skinner, 1953). Discussions of the procedure in the literature tend to be cursory, however, with the notable exception of the use of percentile schedules (e.g., Galbicka, 1994). Shaping has its effects on behavior from differential reinforcement of successive approximations to a specified target behavior. It involves a series of reinforcement and extinction contingencies whereby the consequence during reinforcement establishes a class of responses but the removal of the consequence during extinction increases variability in behavior. From the variations, the next return to reinforcement selects new approximations to the terminal behavior, and so on. Typical laboratory procedures often involve shaping behaviors of individual participants. The procedure, however, can be implemented as effectively to shape the behavior of a group of participants (e.g., Burnstein \& Wolff, 1964), as was occasionally evident in the case presented in Mandela's account. It takes artful practice and experience to implement successfully, and it can be impressively effective. Patience, of course, is indispensable. Once behavior gets going, eventually, the target is realized.

Galbicka (1994) identified four basic verbal rules for the shaping of the behavior of organisms. The first of these rules is to begin at the subject's current repertoire; that is, where the subject's response happens to be presently. The second rule is to explicitly specify the terminal response; that is, where the subject's response will end (the target behavior). The third rule is to use small 
steps toward the target. The final rule is to reinforce movement, rather than position. When followed, these rules are generally effective in establishing new behaviors or reinstituting old ones. The procedure can thus move the behavior back and forth at will to the specification of the shaper. It is important to note, however, that shaping, like many other behavioral processes, is a dynamic and reciprocal process, as illustrated further below.

Various aspects of Galbicka's (1994) rules are discernible in the evidence provided in Mandela's text as outlined below. In addition to these, however, other techniques such as those identified by Skinner (1971) in his discussions on "changing minds" are present; namely, prompting, hinting and suggesting, setting examples, and urging and persuading. As Skinner noted, "[p]rompts, hints, and suggestions are all stimuli usually but not always verbal, and they have the important property of exerting only partial control" (1971, pp. 92-93). As discriminative and/or antecedent stimuli, combining these techniques with the rules outlined by Galbicka, however, present a rather potent arsenal of tools for modifying human behavior in desired directions.

In the case of Mandela and his colleagues, one can only speculate on the specifics of the targets set by the authorities. For example, according to Sparks, having been appointed to the special committee on discussions with Mandela in May 1988, around 1989, "Niël Barnard had a brief to sound the ANC leader [Mandela] out on three issues: Was he prepared to accept that violence was not a way to solve South Africa's political problems? What was his attitude to communism, given the ANC's long-standing alliance with the South African Communist Party? And did he still insist on majority rule, or was he prepared to settle for something else?" (1994, p. 48). A general outline thus is discernible from available accounts that would include either a recommitment to previously held positions or commitments to new ones by Mandela and his colleagues, as determined by the authorities. Whatever the specifics were, undoubtedly, the political outcome that followed in South Africa would be within their frame of reference.

Events and actions of the authorities evident from Mandela's accounts suggest that the authorities had ways and means to achieve that outcome. At least, Sparks' account displays quite a wider array of sources in the authorities' arsenal of information gathering in this regard than is discernible (understandably) from Mandela's account. As shown in Figure 1, the sources included but were not necessarily limited to George Bizos, Mandela's lawyer and Piet de Waal, ${ }^{\text {ii }}$ the lone-lawyer in Brandfort, Orange Free State, where Winnie Mandela was banished in 1977. Both of these men reported to Kobie Coetsee, the minister of justice (see Sparks, 1994, pp. 16-20, 29-31). Also, Pieter de Lange, the Broeder- 
bond chairman, "spoke regularly with [P. W.] Botha" (p. 74), and the academic, Esterhuyse, reported to Niël Barnard, the head of the National Intelligence Service (NIS) just as F. W. de Klerk's brother, Willem de Klerk, reported to his brother (pp. 78-79). This array of resources and networks would have been buttressed, of course, by the discovery of the manuscripts of Mandela's memoirs on Robben Island. The manuscript would have helped them to determine where the ANC leadership, individually and collectively, stood on pertinent political and ideological issues and other matters of interest to the authorities for them to achieve their desired goals. From there, they could set the process in motion. These then represent Rules 1 and 2 of shaping (Galbicka, 1994) in Mandela's case, in rough outline.

Purely from Mandela's own account of events, ${ }^{\text {iii }}$ I think a case can be made that some program was in place, in one form or another, to achieve the state of affairs in the South Africa led by Nelson Mandela. One line of evidence for such a program is a measure of the continuity of contacts by staff with the ANC leadership in captivity, particularly, Mandela. His account indicates a number of durable contacts, some notably covering his stay in Robben Island, Pollsmoor, and Victor Verster Prisons, or combinations there in. Durations of contact, for example, of four years or more include those with Warrant Officer James Gregory, Brigadier Aucamp, Brigadier Fred Munro, General W. H. Willemse, General Steyn, and Jimmy Kruger (see also Sparks, 1994). Sparks noted, "James Gregory... spent a total of twenty-four years guarding Mandela in three different prisons...," (1994, p. 22) for example. He mentions a General Johan Willemse (p. 24) as commissioner of prisons; it is unclear if this refers to W. H. Willemse who held the same position in Mandela's account.

According to Rules 3 and 4 of shaping outlined by Galbicka (1994), differential reinforcement of successive approximations to the target behavior should aim at movement, rather than position, and in small steps. To explore how these rules are represented in Mandela's case, an antecedent-behaviorconsequence $(\mathrm{ABC})$ analysis provides a useful tool, because of the complexity of the interactions among the various protagonists involved, individually and collectively, and the wide ranging events that occur over temporally and environmentally disparate contexts. By using the $\mathrm{ABC}$ units of analysis, we achieve a framework that is consistent with the behavior-analytic perspective from which the thrust of the entire paper derives. The approach adopted in creating the $\mathrm{ABC}$ sequences was simply to try to isolate incidences, personalities, institutions, and events that might have constituted the elements, A, B, and/or C along the way, recognizing the starting (as a "terrorist") and end (as president of South Africa) points in Mandela's narrative. The three (A, B, and C) terms are 


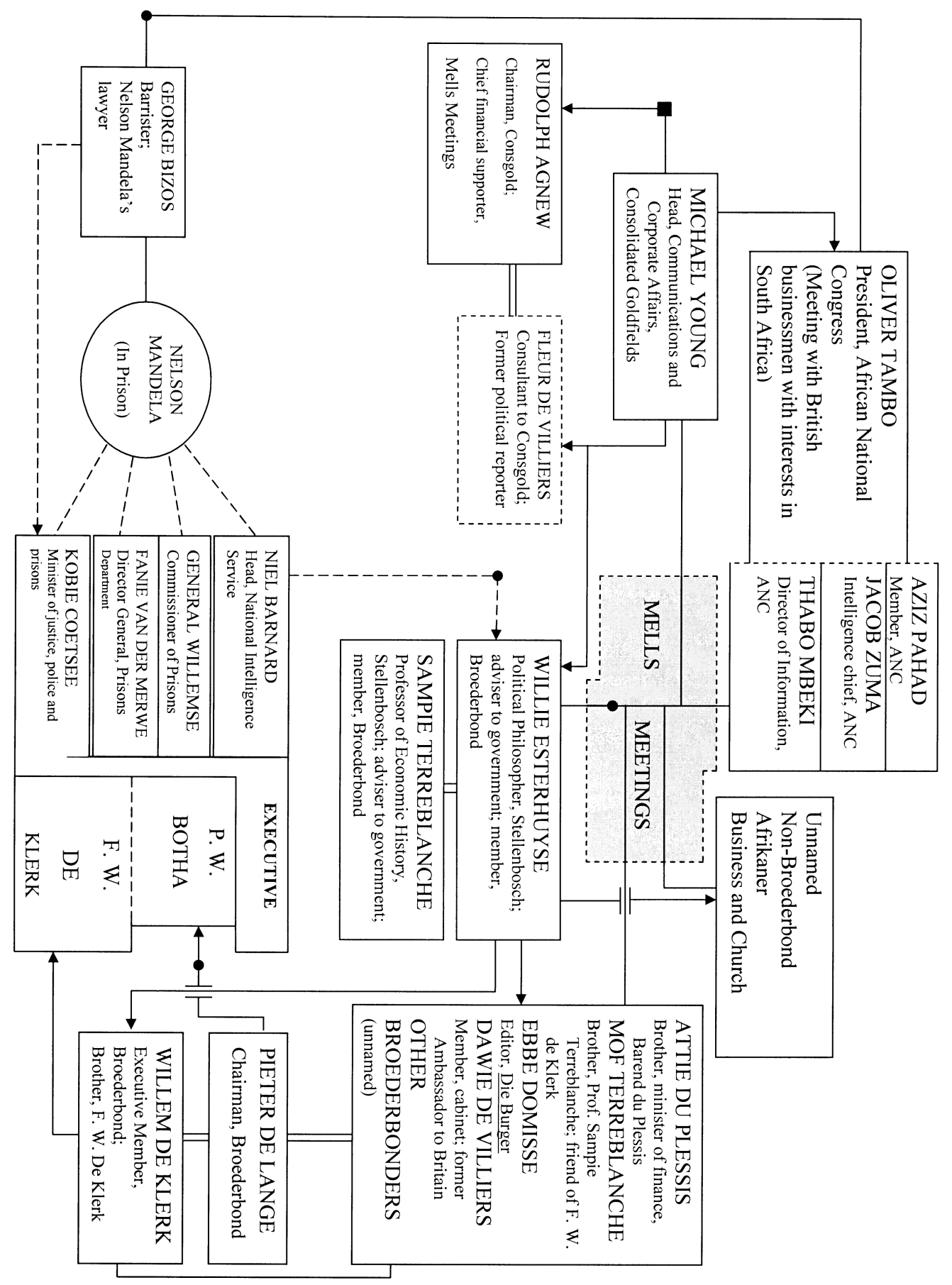

8 (Advance Online Publication) 
Figure 1. A network of contacts between non-South African businessmen, Afrikaner business and church leaders, members and leaders of the Afrikaner Broederbond, academics, and government officials, on the one hand, and the ANC leadership in exile and Nelson Mandela in prison, on the other. Arrow heads indicate points of initial contact; dashed lines indicate lines of clandestine communications with government officials; lines without arrows indicate formal and/or informal meetings; dashed box indicates a one-time contact; and filled dots and square indicate frequent and regular flow of information and/or funds, respectively. Based on Sparks' (1994) accounts.

used in the broadest sense as organizing aids without pretext to specialized usage as in, for example, distinguishing among discriminative, motivational, and/or general contextual antecedents. Significant as well was how the world and the authorities perceived him (e.g., as saint and leader, respectively) and his roles at various points in the journey. In considering these, recognizing how, when, and why movement occurred in his behavior or views, as well as of those in authority, was critical. Absent any specific psychological analysis or point of view in his narrative, these elements had to be "extracted," so to speak, from its pages. Consequently, temporal gaps in the $\mathrm{ABC}$ sequences appear in the presentation, which mostly, but not necessarily always, correspond to gaps in the events and persons described in Mandela's narrative.

\section{An ANTECEDENT-BeHAVIOR-CONSEQUENCE ANALYSIS}

The apartheid authorities released Mandela from prison in February 1990 after a long process of what might be characterized as negotiations. I will argue in the following, however, that his account of the events leading to that point suggests some program of conditioning, a process, I believe, that might have begun some twenty years before. Accordingly, the shaping process appears to have evolved over four general phases beginning early, in earnest, in the Robben Island prison; indeed, soon upon the arrival of Mandela and the other high caliber political prisoners on the island. The followings represent some evidence in the form of $\mathrm{ABC}$ units (some presented in frames) to illustrate the shaping contingencies discernible from Mandela's account.

\section{Phase 1: Robben Island Prison}

Phase 1 took place on Robben Island. It consisted of disciplinary actions by the prison authorities, their active selection of Nelson Mandela from among his colleagues who were his coequals and superiors, both in age and "rank," and the assumption of leadership roles by Mandela among his colleagues, the general

prison population, and in Transkei politics. Some evidence on each of these 
aspects follows next in the form of $\mathrm{ABC}$ sequences. The events or incidences are in rough chronological order.

Discipline. The first steps taken by the authorities were to establish obedience and subservience firmly among the new arrivals by imposing very severe penalties for not following orders. Several ABC events involving disciplinary action to control, modify, or curtail the behavior of Mandela and his colleagues in captivity occurred early during their incarceration. Countercontrol incidents or measures are indicated in parentheses where they occur.

The first disciplinary incident occurred soon after Mandela and his colleagues arrived on Robben Island in 1964. When a prison guide asked one of his colleagues, Kathy, to take a wheelbarrow filled with gravel to a truck (A), Mandela attempted to help him (B), resulting in severe consequences for not only Mandela and Kathy, but all the political prisoners in their group ( $\mathrm{C}$; collective). They were to half-fill a large skip by the week's end. In protest, the group decided on a go-slow strike (B; collective; countercontrol), which resulted in an even more severe penalty for as long as the strike continued; three-quarters skip by week 2 and full skip by week 3 (C; collective). In a second incidence, two weeks into their prison term, Mandela was presented with short trousers (A) but he demanded to see the head of prison (HOP) with a list of complaints (B). His requests were ignored by the warders initially but were finally granted $(\mathrm{C})$, only for Mandela to refuse (B; countercontrol) because similar trousers were not issued for his colleagues. The HOP himself took away the pair from Mandela (C). The latter incidence appears designed to show Mandela that when a bridge of order was to occur, it would have to be on terms set by the authorities. Another disciplinary incidence occurred the following year when Mandela was placed in four days of isolation (C) for disobeying orders to return to work (B) at the quarry during a visit by Brig. Aucamp with the Commanding Officer (CO; A). Insubordination was not to be tolerated, especially not when it was against the wishes of the prison authorities. Yet another disciplinary incidence occurred sometime in 1971 after Col. Piet Badenhorst arrived on the island as CO and amidst worsening prison conditions. Badenhorst had provoked (A) Mandela into insolence, the latter angrily approached without orders to do so (B), resulting in collective punishment for all the men at the quarry (C; collective). Nevertheless, Mandela was still pinpointed as a scapegoat to restore order $(\mathrm{C}$; individual; see Frame 1).

Selection of Mandela for leadership roles. To appreciate the full extent of this aspect of the process under consideration, one must understand that, quite early on, the authorities appeared to nurture Mandela's leadership potential on Robben Island, not only among the general inmates, but also within the High Organ and 
Frame 1. Amidst improved prison conditions (Chapter 71), conversations with warders-Boss escape plan through a warder in 1969; end of 1970, Col. van Aarde replaced by Col. Piet Badenhorst (PB) as CO cutting short the former's tenure (443444) and turning back the clocks on improvement in prison life and conditions (444-45)

\begin{tabular}{|c|c|c|c|}
\hline Date & Antecedent & Behavior & Consequence \\
\hline $\begin{array}{l}1971 ? \\
\text { One week after } \\
\text { PB's arrival }\end{array}$ & $\begin{array}{l}\text { PB: "Mandela, you } \\
\text { must pull your } \\
\text { finger out of your } \\
\text { arse" (an insult) } \\
\text { (individual) }\end{array}$ & $\begin{array}{l}\text { NM angrily } \\
\text { approaches PB (B) }\end{array}$ & $\begin{array}{l}\text { PB ordered all back } \\
\text { to their prison } \\
\text { section; addresses } \\
\text { them, drops their } \\
\text { classifications by } \\
\text { one (collective } \\
\text { effect) and then } \\
\text { pinpoints NM as } \\
\text { scapegoat to restore } \\
\text { order (individual) }\end{array}$ \\
\hline
\end{tabular}

among the other political prisoners. Indications to this effect include their initial insistence that there be no spokesman among the prisoners, on the one hand, and the manner in which prison rules and regulations were selectively applied and enforced by the prison authorities, on the other. According to Mandela,

The prison service regulations were explicit that each prisoner was permitted to speak only for himself. This was done to negate the power of organization and to neutralize our collective strength... We were not even permitted to use the word we when we make complaints [emphasis in original]. But during the first few years, when the authorities needed one prisoner to speak on behalf of others, that individual would be me. (1994, p. 382; my emphases)

He provides ample evidence. For example, by the end of their second week on the island, Bram Fisher and Joel Joffe had paid them their first attorney's visit since the trials (A). Mandela offered (B) to write a condolence letter to Bram for loss of his wife, which he did and submitted to the major, but it was not mailed (C). Only days afterwards, Mandela was taken with others to the head office for finger printing, etc. (A), for which he demanded to see authorization documents as required by regulations (i.e., speaking for the others; B), but was not sanctioned for the challenge; not only was he not sanctioned, the photos were not taken either (C). This is, of course, in sharp contrast to the usual disciplinary actions the authorities dished out for disobedience of orders. This appears to represent a 
successive approximation to the kind of leadership roles Mandela was intended to assume among inmates. For, a few weeks subsequently, the London-based Daily Telegraph reporters visited the prison on what was the first such official visit to the prisoners. Against prison regulations, Mandela was chosen to speak on behalf of the others. During a subsequent visit by Hynning from the American Bar Association, the other prisoners chose Mandela to speak for them when they were asked to choose a spokesman by General Steyn. Soon afterwards, warders beat up a PAC member, Ganya (A). Mandela took up his case as an attorney and demanded that the warder be removed from the island (B). His request was initially refused, but shortly after, the warder was transferred from Robben Island (C). Indeed, when the Red Cross visited later, Mandela was the one called to the head office. Effectively, Mandela was assuming a veritable role among his coequals and superior colleagues as de facto leader of the group both in the ANC leadership in captivity and in the general prison population.

Mandela's assumption of leadership roles. The process continued, of course. The next stage presented further instances illustrating how Mandela's role as leader among the prison population was promoted by a series of successive approximations, leading to substantive leadership role-playing. Many of the incidences here represent countercontrol (identified below) for the most part. Mandela began to take leadership initiatives, initially with others. Some time about 1965, for example, there had been warder hostility at the quarry (A), Mandela assigned a comrade to befriend a warder who took the latter's jacket to sit on, and Mandela lets the comrade accept a sandwich the warder threw on the ground (B; collaborative). The warder became friendly to them and asked about the ANC, etc. (C; collective). In a different example in September 1966, Verwoerd had been stabbed to death, and white South Africa was in shock (A). The anger spilled over to affect life severely on Robben Island, as personified by the viciousness of Von Rensburg to the political prisoners at the quarry (B). Mandela organized a legal advisory team with Mac and Fiki for other inmates to forestall the increasing prison court actions against inmates (C; countercontrol). Subsequently, however, Mandela began to take these initiatives by himself.

After May 1971, following the aforementioned disciplinary downgrading of the political prisoners' classification and scapegoating of Mandela (see Frame 1), the three Cape judges visited in summer of 1971 (A). During their visit, Mandela complained to them about assaults and other matters (B; see Mandela, 1994, pp. 448 for exchange). The harsh conditions in prison abated thereafter and three months later, the HOP and other aggressive warders were transferred from Robben Island (C). At this point, Col. Willemse took charge, marking the beginning of good things to come. Interestingly, it was Col. Willemse who, much 
like in the mid-1960s, bent the prison rules. Subsequent events showed how when the prisoners started to talk rather than work at the quarry (A), Willemse, against prison regulations, allowed Mandela to organize a general meeting (B) during which the prisoners decided that they would appear to work (C). That quelled complaints and "work" resumes (countercontrol). Once during 1971-72, a dispute between an MK man, Jimmy April, and a prison official over a letter arose (A), and Mandela intervened, preventing an "attack" from Jimmy (B). One week later, Mandela was the one the prison official handed the letter to, not Jimmy (C). By 1972 when Lt. Terblanche was HOP, the prison atmosphere was so relaxed (A) that he partook in the prisoners' mussel (B) and, rather than take punitive action, simply praised their food (C; countercontrol).

A series of incidents occurred in the mid-1970s (Frame 2; note that grayed events represent countercontrol incidents) that may have served as important contexts for subsequent events. Zindzi had visited Mandela. After the visit, Lt. Prin, the then HOP made insulting remarks about Mandela's wife (A). Mandela was angry and was verbally abusive $(\mathrm{B})$. Charged $(\mathrm{C}, \mathrm{A})$, Mandela brought a countersuit $(\mathrm{C}, \mathrm{B})$ for which he prepared a case with G. Bizos as his lawyer, brought it to court himself (A), the case against him was withdrawn (B; countercontrol), and his prepared case was confiscated, providing access to Mandela's case documents (C; countercontrol; see Frame 2 for further details). It was during this period too that the authorities discovered his memoirs. Both of these incidents, in my view, would have provided considerable insight for the authorities into Mandela's thinking, legal and political, on matters of great significance to them. For example, after the memoirs were seized (A), Jimmy Kruger, the minister of prison himself paid him a visit on Robben Island to urge him to recognize the Transkei government (B). Similar offers were made subsequently and Mandela turned them all down (C; countercontrol; see Frame 2).

By 1980, Transkei politics took a different turn. Matanzima, Mandela's nephew, deposed Sabata Dalindyebo as King of the Thembus (A). The authorities approved a meeting sought by Thembu chiefs (B) and, against the wishes of his colleagues on Robben Island, Mandela met with them (C). However, when Matanzima sought another approved audience with Mandela with government approval (A) and the latter was met with very strong objections from members of the High Organ and people in the general prison population (B), Mandela turned down the visit (C). In March 1982, Mandela was informed that his wife, Winnie Mandela, was involved in an automobile accident and was in hospital, but nothing more (A). Mandela wanted to see his lawyer, but his wife's lawyer came instead 
Frame 2.

\begin{tabular}{|c|c|c|c|}
\hline Date & Antecedent & Behavior & Consequence \\
\hline $\begin{array}{l}1975, \\
\text { Month after } \\
\text { Zindzi's visit (a) }\end{array}$ & $\begin{array}{l}\text { Lt. Prins insults } \\
\text { WM }\end{array}$ & $\begin{array}{l}\text { NM angry, verbally } \\
\text { abusive }\end{array}$ & $\begin{array}{l}\text { NM charged next } \\
\text { morning; arranges a } \\
\text { countersuit charge } \\
\text { with G. Bizos as } \\
\text { lawyer }\end{array}$ \\
\hline (b) & $\begin{array}{l}\text { Case brought to } \\
\text { court; NM with } \\
\text { prepared case }\end{array}$ & $\begin{array}{l}\text { Case against NM } \\
\text { withdrawn; a } \\
\text { warrant officer } \\
\text { confiscates NM's } \\
\text { file }\end{array}$ & $\begin{array}{l}\text { Access to NM's } \\
\text { case documents }\end{array}$ \\
\hline $\begin{array}{l}1976 \\
\text { (c) }\end{array}$ & $\begin{array}{l}\text { The authorities had } \\
\text { discovered NM's } \\
\text { memoirs (in 1975) }\end{array}$ & $\begin{array}{l}\text { Jimmy Kruger } \\
(\mathrm{JK}), \text { minister of } \\
\text { prisons visits NM, } \\
\text { urging recognition } \\
\text { of Transkei } \\
\text { government }\end{array}$ & $\begin{array}{l}\text { NM rejected } \\
\text { Bantustan policy } \\
\text { and offer (same one } \\
\text { month later) }\end{array}$ \\
\hline
\end{tabular}

on March 31, after which he returned to his cell (B). Soon after the lawyer left, however, the $\mathrm{CO}$ entered Mandela's cell with other prison officials and was told to get ready for transfer for an undisclosed destination with Walter, Mhlaba, and Mlangeni (C). This marked the end of Phase 1, beginning the process of isolation of Mandela from certain influences in the ANC High Organ on Robben Island.

\section{Phase 2: Pollsmoor Prison ${ }^{i v}$}

The themes of the second phase included continued isolation of Mandela, intensified by his further isolation from the group of colleagues moved with him to the Pollsmoor Prison. The primary aim of this phase appears to have been to obtain specific formulations of policies and expressions of political ideas and goals by Mandela on the future of South Africa. This was accomplished through a good measure of verbal shaping. In addition, the authorities sought and got specific commitments from Mandela. 
By 1985, the ANC High Organ on Robben Island, with Mlangeni, had moved up the luxury scale to Pollsmoor Prison, to be joined a few weeks later by Kathrada, their chief of communications on Robben Island. In late 1984 and early 1985, the minister of justice, Kobie Coetsee, authorized two important visits, one from Lord Nicholas Bethel of the British House of Lords and European Parliament, and another from Professor Samuel Dash of Georgetown University. During these meetings, Mandela expressed his political views, with South African officials present in one of them. Armed with such position statements, the apartheid government was prepared for a political response of its own. On 31 January 1985, P. W. Botha challenged Nelson Mandela to renounce violence for his freedom (see Frame 3) - this, according to Mandela, being the sixth such offer in ten years, and he had been prompted by the authorities to expect it, only they did not say it would be made in Parliament. ${ }^{\mathrm{N}}$

That same year, instead of replying to a letter Mandela had written to him pressing for talks, the minister of justice pays him a personal visit at Volks hospital $^{\mathrm{vi}}$ where he had undergone surgery for an enlarged prostate gland (see Frame 4, a). Upon discharge from the hospital, Brigadier Munro, the CO himself picked up Mandela, an unusual occurrence in the South African prison system. Moreover, upon arriving Pollsmoor, he was taken to a new cell, effectively separated from the High Organ, and thence, alone (see Frame 4, b). It was in this "splendid isolation" (Mandela, 1994, p. 514) that Mandela began to pursue, unilaterally, talks with the government (see Frame 4, c), clandestinely! In early 1986, Mandela had been fitted for an outfit in preparation for a meeting with the Eminent Persons Group (EPG) vii when a smiling Brig. Munro retorted, "Mandela, you look like a prime minister now, not a prisoner" (1994, p. 517; Frame 4, d). This was verbal priming per force; technically known as prompting, such verbal statement would serve as a cue for Mandela's behavior or performance at the impending meeting with General Olusegun Obasanjo of the EPG. That he did perform well is reflected in the impression he gave even Coetsee at the start of that meeting.

At the meeting with General Obasanjo, Mandela had requested another meeting with all the members of the EPG. A meeting was set for May 1986. At that meeting, Mandela expressed a number of very important political positions. Coetsee and General Willemse were present for a part of the meeting. In effect, Mandela told the group that Oliver Tambo was the ANC leader and they should speak to him; he favors dialogue with government, but he was not ready to renounce violence, even though violence was not an ultimate solution. Instead, he desired withdrawal of government troops from the townships and warned that his own release would not reduce the violence raging in the townships. Just before the 
Frame 3.

\begin{tabular}{|c|c|c|c|}
\hline Date & Antecedent & Behavior & Consequence \\
\hline $\begin{array}{l}\text { Late 1984,early } \\
1985\end{array}$ & $\begin{array}{l}\text { Government testing } \\
\text { the waters: Kobie } \\
\text { Coetsee (KC) } \\
\text { approves visits for } \\
\text { Lord Bethel (1984) } \\
\text { and Prof. Dash } \\
\text { (1985) }\end{array}$ & $\begin{array}{l}\text { During meetings, } \\
\text { NM discusses: } \\
\text { - conditions at PP } \\
\text { - armed struggle: } \\
\text { government to } \\
\text { renounce violence, } \\
\text { not ANC } \\
\text { - ANC targets } \\
\text { military, not people } \\
\text { (with Bethel; Maj. } \\
\text { Sittert present to } \\
\text { monitor) } \\
\text { - minimum } \\
\text { requirements for } \\
\text { non-racial South } \\
\text { Africa (SA): } \\
\text { + unitary state } \\
\text { + no homelands } \\
\text { + non-racial } \\
\text { elections } \\
\text { + one-person, one- } \\
\text { vote } \\
\text { - need for political } \\
\text { equality, not } \\
\text { cosmetic changes; } \\
\text { could make } \\
\text { governing difficult } \\
\text { for government } \\
\text { (with Dash; no } \\
\text { mention of SA } \\
\text { officials present) }\end{array}$ & $\begin{array}{l}31 \text { January 1985, P. } \\
\text { W. Botha } \\
\text { challenges NM } \\
\text { specifically to } \\
\text { renounce violence } \\
\text { for his freedom; } \\
\text { NM granted request } \\
\text { to see wife and } \\
\text { lawyer after a } \\
\text { week's delay } \\
\text { (meeting allowed } \\
\text { Friday, } 8 \\
\text { February), NM's } \\
\text { response to Botha } \\
\text { read at the UDF } \\
\text { rally, Sunday } 10 \\
\text { February. }\end{array}$ \\
\hline
\end{tabular}

next agreed meeting with the EPG, P. W. Botha ordered raids on ANC targets in Botswana, Zambia, and Zimbabwe, and the EPG left South Africa in protest and Mandela's efforts appeared stalled (Frame 5). It remains unclear what specific part of Mandela's stated positions (e.g., that Tambo was the ANC leader or that 
Frame 4.

\begin{tabular}{|c|c|c|c|}
\hline Date & Antecedent & Behavior & Consequence \\
\hline $\begin{array}{l}1985 \\
\text { (a) }\end{array}$ & $\begin{array}{l}\text { NM had written to } \\
\text { KC, no reply; NM } \\
\text { admitted to Volks } \\
\text { for surgery }\end{array}$ & $\begin{array}{l}\text { KC makes personal } \\
\text { visit to NM at } \\
\text { bedside; NM } \\
\text { requests permission } \\
\text { for WM to remain } \\
\text { in Johannesburg; } \\
\text { KC promises to } \\
\text { look into it; NM } \\
\text { thanks him }\end{array}$ & $\begin{array}{l}\text { An "olive branch" } \\
\text { from government }\end{array}$ \\
\hline $\begin{array}{l}\text { 1985: days after } \\
\text { return from Volks } \\
\text { (b) }\end{array}$ & $\begin{array}{l}\text { NM separated from } \\
\text { High Organ; to see } \\
\text { them, has to seek } \\
\text { approval from } \\
\text { Pretoria head } \\
\text { office and } \\
\text { conversations are } \\
\text { monitored! }\end{array}$ & $\begin{array}{l}\text { NM requests a visit } \\
\text { few days upon } \\
\text { return from Volks } \\
\text { hospital; meeting } \\
\text { granted; others } \\
\text { angry at the } \\
\text { separation, but NM } \\
\text { persuades them not } \\
\text { to protest it }\end{array}$ & $\begin{array}{l}\text { NM in "splendid } \\
\text { isolation" free to } \\
\text { act on his own. }\end{array}$ \\
\hline $\begin{array}{l}1985 \text { after a few } \\
\text { weeks alone } \\
\text { (c) }\end{array}$ & NM alone & $\begin{array}{l}\text { NM writes two } \\
\text { letters to KC "to } \\
\text { propose talks about } \\
\text { talks." }\end{array}$ & $\begin{array}{l}\text { No replies; NM } \\
\text { seeks other } \\
\text { "opportunities to be } \\
\text { heard" }\end{array}$ \\
\hline $\begin{array}{l}\text { Feb. } 1986 \\
\text { (d) }\end{array}$ & $\begin{array}{l}\text { Two days before } \\
\text { EPG meeting }\end{array}$ & $\begin{array}{l}\text { Brig. Munro brings } \\
\text { tailor to outfit NM } \\
\text { for a suit: } \\
\text { "Mandela, we want } \\
\text { you to see these } \\
\text { people on an equal } \\
\text { footing. We don't } \\
\text { want you to wear } \\
\text { those old prison } \\
\text { clothes, so this } \\
\text { tailor will take your } \\
\text { measurements and } \\
\text { outfit you with a }\end{array}$ & $\begin{array}{l}\text { Munro: "Mandela, } \\
\text { you look like a } \\
\text { prime minister } \\
\text { now, not a } \\
\text { prisoner," with a } \\
\text { smile. (517) }\end{array}$ \\
\hline
\end{tabular}


proper suit"; tailor

returns following

day with suit and

complete wear; NM

wears them...

he wanted troop withdrawals, etc.) triggered such massive reaction. In June 1986, a state of emergency was declared nationwide in response to ANC-organized protests designed to make South Africa ungovernable. Mandela requested a meeting with Gen. Willemse and was taken promptly to Willemse from where he was taken to see Coetsee for a three-hour long conversation. During this meeting, Mandela requested a meeting with P. W. Botha, but never got one (see Frame 6, a-c). Mandela kept seeking dialogue with the government and the government kept responding with small but important gestures (see Frame 7), not dialogue. Apparently, requests for talks with the government were not the target behavior desired by the authorities in Mandela's repertoire. Nevertheless, the process of shaping requires that intermediate behaviors be reinforced adequately, or they may be extinguished inadvertently. Hence, the "small pleasures" of Pollsmoor.

Furthermore, prison staffs were taking him out on tours of the city of Cape Town. On the many tours given Mandela from Pollsmoor, Coetsee was quoted as saying: "What we had in mind was to expose him to the realities of the outside world, to prepare him for release" (Sparks, 1994, p. 38). On the early easing of conditions on Robben Island (see Part 9, Mandela, 1994), Coetsee had stated that he was sure "Mandela and his colleagues would have to be released sometime and that they should be prepared for that" (Sparks, 1994, p. 22; my emphases). From all accounts, however, it seems only Mandela was receiving this preparation, indicating Mandela's special status in the authorities' scheme of things (see James Gregory's comments on these excursions and his official instructions in Sparks, 1994, pp. 42, 44-45). The tours were certainly part of the "small pleasures" of Pollsmoor, albeit extended only to Mandela (see note 7). Not surprisingly (see further discussions below), all the while, he was not in dialogue with his colleagues in Lusaka or three floors above him in Pollsmoor Prison.

In 1987, when Coetsee informed Mandela of a presidential committee to meet with him for private discussions (A), he agreed to the committee but wanted to inform his other colleagues in Pollsmoor (B). Only after Mandela complained to top officials was he allowed to talk to them, but only individually (Frame 8)! This, then, was a "splendid isolation" that would have been rather conducive to a program of conditioning of Mandela's individual actions, verbal and otherwise. 


\begin{tabular}{|c|c|c|c|}
\hline \multicolumn{4}{|l|}{ Frame 5.} \\
\hline Date & Antecedent & Behavior & Consequence \\
\hline Early Feb. 1986 & $\begin{array}{l}\text { NM, meeting with } \\
\text { Gen. Obasanjo, } \\
\text { head of EPG, seeks } \\
\text { meeting with the } \\
\text { whole group; } \\
\text { meeting set for } \\
\text { May }\end{array}$ & $\begin{array}{l}\text { May 1986: at the } \\
\text { meeting, KC and } \\
\text { Lt. Gen. Willemse, } \\
\text { Commissioner of } \\
\text { Prison (COP) } \\
\text { present initially } \\
\text { then left; with EPG, } \\
\text { NM: } \\
\text { - Oliver Tambo is } \\
\text { leader of ANC } \\
\text { - They speak to him } \\
\text { in Lusaka } \\
\text { - His (NM's?) } \\
\text { views are personal } \\
\text {-Favors ANC } \\
\text { starting dialogue } \\
\text { with government } \\
\text { - SA nationalists, } \\
\text { not communists } \\
\text { - Firmly committed } \\
\text { to non-racial society } \\
\text { - Believe in } \\
\text { Freedom Charter } \\
\text { - White minority } \\
\text { should feel secure } \\
\text { in new SA } \\
\text { - Talks will resolve } \\
\text { ANC-government } \\
\text { misunderstandings } \\
\text { - Not yet willing to } \\
\text { give up violence } \\
\text { - Violence not } \\
\text { ultimate solution } \\
\text { - Suggests } \\
\text { withdrawal of army } \\
\text { and police from } \\
\text { townships for ANC }\end{array}$ & $\begin{array}{l}\text { Day before next } \\
\text { meeting with the } \\
\text { EPG, P. W. Botha } \\
\text { orders raids on } \\
\text { ANC targets in } \\
\text { Botswana, Zambia, } \\
\text { and Zimbabwe; } \\
\text { EPG leaves SA; } \\
\text { talks "poisoned," } \\
\text { NM's efforts } \\
\text { "stalled." }\end{array}$ \\
\hline
\end{tabular}


to suspend armed

struggle

- Own release won't

stem violence

(EPG to return

again same month,

May, after Lusaka

and Pretoria)

\section{Phase 3: Victor Verster Prison}

Discussions eventually began in 1988, with a team of President P. W. Botha's working group consisting of the minister of justice, commissioner of prisons, director general of prisons, and head of National Intelligence Services (a curious addition, even to Mandela, but it did not matter to him). By December 1988, Mandela was moved to a cottage of his own, now, not in Pollsmoor, but Victor Verster. The transfer of Mandela to Victor Verster was highly significant, as was the sequence of events leading to it. In May 1988, the first of the meetings with the president's committee had began and was held, according to Mandela, "almost every week for a few months, then... at irregular intervals, sometimes not for a month, and then suddenly every week. The meetings were usually scheduled by the government, but sometimes I would request a session " (Mandela, 1994, p. 525; my emphases). The subjects of discussion included the armed struggle, the ANC-SACP alliance, nationalization of the economy, and majority rule (Mandela, 1994, pp. 525-527), all but one - namely, nationalization - being the issue on which Niël Barnard has been reported to hold briefs (Sparks, 1994, p. 48). Sparks noted, "Mandela for his part, was single-minded in wanting a meeting with President Botha..." (1994, p. 48; my emphases). According to Mandela, "[t]he meetings had a positive effect: I was told in the winter of 1988 that President Botha was planning to see me before the end of August" (1994, p. 528; my emphases). The promise of a pending meeting only served as a verbal bridge, it appears, as the meeting did not hold until July 5, 1989, after some 7 months at the cottage in Victor Verster. Thus, at the time he was moved to the cottage, "the meetings with the committee continued, but we were stalled on the same issues that had always prevented us from moving forward: the armed struggle, the Communist Party, and majority rule" (Mandela, 1994, p. 535). 


\begin{tabular}{|c|c|c|c|}
\hline \multicolumn{4}{|l|}{ Frame 6.} \\
\hline Date & Antecedent & Behavior & Consequence \\
\hline $\begin{array}{l}\text { June } 1986 \\
\text { (a) }\end{array}$ & $\begin{array}{l}\text { State of Emergency } \\
\text { in response to } \\
\text { nationwide } \\
\text { upheaval, courtesy } \\
\text { of ANC call for } \\
\text { ungovernability of } \\
\text { SA }\end{array}$ & $\begin{array}{l}\text { NM wrote to Gen. } \\
\text { Willemse wishing } \\
\text { to see him "on a } \\
\text { matter of national } \\
\text { importance" (on a } \\
\text { Wednesday) }\end{array}$ & $\begin{array}{l}\text { By weekend, NM } \\
\text { summoned by CO } \\
\text { to Willemse's } \\
\text { residence in } \\
\text { Pollsmoor for a } \\
\text { meeting. }\end{array}$ \\
\hline $\begin{array}{l}\text { Same day } \\
\text { (b) }\end{array}$ & $\begin{array}{l}\text { At Willemse's } \\
\text { residence in } \\
\text { Pollsmoor }\end{array}$ & $\begin{array}{l}\text { NM: "I want to see } \\
\text { the minister }[\mathrm{KC}] \text { in } \\
\text { order to raise the } \\
\text { question of talks"; } \\
\text { Willemse phoned in } \\
\text { to Cape Town; } \\
\text { minister said: } \\
\text { "Bring him around." }\end{array}$ & $\begin{array}{l}\text { Within minutes, } \\
\text { they left for KC's } \\
\text { official residence in } \\
\text { Cape Town. }\end{array}$ \\
\hline $\begin{array}{l}\text { Same day } \\
\text { (c) }\end{array}$ & $\begin{array}{l}\text { At KC's official } \\
\text { residence in Cape } \\
\text { Town, during three } \\
\text { hours of } \\
\text { conversation, KC: } \\
\text { - What } \\
\text { circumstances to } \\
\text { renounce armed } \\
\text { struggle } \\
\text {-Whether or not } \\
\text { NM spoke for the } \\
\text { ANC as a whole } \\
\text { - Constitutional } \\
\text { guarantees for } \\
\text { minorities in a new } \\
\text { SA; } \\
\text { NM responds as par } \\
\text { EPG, then, KC: } \\
\text { "what is the next } \\
\text { step?" }\end{array}$ & $\begin{array}{l}\text { NM wants to meet } \\
\text { P. W. Botha and P. } \\
\text { K. Botha (foreign } \\
\text { minister); KC takes } \\
\text { notes, promises to } \\
\text { channel information }\end{array}$ & $\begin{array}{l}\text { Both shake hands, } \\
\text { NM returns to } \\
\text { Pollsmoor to await } \\
\text { response; but } \\
\text { "nothing happened. } \\
\text { Weeks and then } \\
\text { months passed } \\
\text { without a word } \\
\text { from Coetsee. In } \\
\text { some frustration, I } \\
\text { wrote him another } \\
\text { letter" (519) }\end{array}$ \\
\hline
\end{tabular}




\begin{tabular}{|c|c|c|c|}
\hline \multicolumn{4}{|l|}{ Frame 7.} \\
\hline Date & Antecedent & Behavior & Consequence \\
\hline $\begin{array}{l}\text { Dec } 1986 \\
\text { Christmas Eve }\end{array}$ & $\begin{array}{l}\text { Awaiting KC's } \\
\text { response; Lt. Col. } \\
\text { Gawie Marx, (GM) } \\
\text { deputy CO, } \\
\text { casually asks NM } \\
\text { out: "Mandela, } \\
\text { would you like to } \\
\text { see the city?" --they } \\
\text { drove around Cape } \\
\text { Town. After one } \\
\text { hour, GM stops at a } \\
\text { "quiet street" shop: } \\
\text { "Would you like a } \\
\text { cold drink?"; went } \\
\text { into the shop, } \\
\text { leaving NM } \\
\text { unguarded "for the } \\
\text { first time in twenty- } \\
\text { two years" }\end{array}$ & $\begin{array}{l}\text { NM did not attempt } \\
\text { to escape }\end{array}$ & $\begin{array}{l}\text { Col. Marx returns } \\
\text { with two cans of } \\
\text { Coca-Cola (the first } \\
\text { of many such trips } \\
\text { to follow, while } \\
\text { waiting for a } \\
\text { response from KC) }\end{array}$ \\
\hline \multicolumn{4}{|c|}{$\begin{array}{l}\text { "Much as I enjoyed these little adventures, I well knew that the authorities had a motive } \\
\text { other than keeping me diverted. I sensed that they wanted to acclimatize me to life in } \\
\text { South Africa and, perhaps at the same time, get me so used to the pleasures of small } \\
\text { freedoms that I might be willing to compromise in order to have complete freedom." } \\
\text { P. S.: "These trips were instructive on a number of levels. I saw how life had changed in } \\
\text { the time I had been away, and because we mainly went to white areas, I saw the } \\
\text { extraordinary wealth and ease that whites enjoyed..." (521) }\end{array}$} \\
\hline
\end{tabular}

Notably, the issue of nationalization was no longer an obstacle and, by then, given the high frequency of the meetings, Mandela's views on the three issues were well known to the committee; indeed, he was preparing a memorandum to present to President Botha. So, the delays in meeting Botha were having the desired effect of generating a great deal of verbal output by Mandela on matters of great interest to the committee. These represented verbal commitments on Mandela's part (see Mandela, 1994, pp. 535-536 on the memorandum, for example). Indeed, con- 
Frame 8.

\begin{tabular}{|c|c|c|c|}
\hline Date & Antecedent & Behavior & Consequence \\
\hline $\begin{array}{l}1987 \\
\text { (a) }\end{array}$ & $\begin{array}{l}\text { KC informs NM of } \\
\text { formation of "a } \\
\text { committee of senior } \\
\text { officials to conduct } \\
\text { private discussions } \\
\text { with me" with the } \\
\text { "full knowledge" of } \\
\text { P. W. Botha }\end{array}$ & $\begin{array}{l}\text { NM consents to the } \\
\text { members of the } \\
\text { committee and } \\
\text { requests to meet his } \\
\text { Pollsmoor } \\
\text { colleagues }\end{array}$ & $\begin{array}{l}\text { The "authorities } \\
\text { summarily refused" }\end{array}$ \\
\hline (b) & Meeting refusal & $\begin{array}{l}\text { NM complained to } \\
\text { high officials }\end{array}$ & $\begin{array}{l}\text { Meeting approved } \\
\text { individually, rather } \\
\text { than collectively! }\end{array}$ \\
\hline \multicolumn{4}{|c|}{$\begin{array}{l}\text { Winter 1988, NM informed he would meet P. W. Botha before the end of August; NM } \\
\text { fell ill with bad cough, taken to Tygerberg Hospital, University of Stellenbosch, TB } \\
\text { discovered, operation performed; six weeks later, NM transferred to Constantiaberg } \\
\text { Clinic near Pollsmoor; secret meeting continued here with the committee; and KC tells } \\
\text { NM he would be going to a "halfway between confinement and freedom" (530); } \\
\text { nursing staff organized party for NM - they were whites and coloreds (528-31); } \\
\text { December 1988, NM taken to a cottage in Victor Verster Prison (VVP) north east of } \\
\text { Cape Town (532); KC visits with a case of Cape wine as a gift, and tells NM this was a } \\
\text { place he could "hold discussions in privacy and comfort," and would be his last abode } \\
\text { before freedom (533); official cook provided; many and increasing visits from ANC, } \\
\text { UDF, and MDM members with entertainments, meals, wines, etc., (534); limited } \\
\text { contacts with colleagues at Pollsmoor, Robben Island or Lusaka (535). }\end{array}$} \\
\hline
\end{tabular}

cerning the meeting with Botha, Sparks wrote: "As Coetsee says, after that [meeting] there was no way of stopping the process. It was just a matter of timeand the man" (1994, p. 56; my emphases). In addition, by all accounts, the cottage from which Mandela was initiating these talks was a potent reinforcer for Mandela's verbally expressed positions up to that point. That Mandela obtained the plans of the cottage and "had an exact replica built as his holiday home at Qunu, his birthplace in Transkei, is evidence of the potency of the pleasures of Victor Verster" viii (see Sparks, 1994, p. 41; see also Mandela, 1994, p. 599). By his move to Victor Verster, then, Mandela was "free" to consult with ANC, 
United Democratic Front (UDF) and Mass Democratic Movement (MDM) members who came and went to the cottage, where he entertained them, courtesy of the State.

\section{Phase 4: Free}

Talks continued. By October 1989, de Klerk had become president, talks continued, and Walter Sisulu and seven others were released from prison. Four months later, Mandela followed. Thereafter, notwithstanding inopinate escalations in violence all over South Africa, the talks continued, culminating in an election and the inauguration of Mandela as President in a government of national unity, based on proportional representation or power sharing.

\section{SYNOPSIS AND DISCUSSION}

It appears that once the authorities got Mandela talking about talking, the business of shaping was well underway; what remained was fine-tuning, to get him saying whatever they wanted to hear, in the form of commitments to desired positions and denouncement of undesirable positions. Indeed, this would be consistent with any program of behavior change. As Miller rightly pointed out,

Regardless of the moral considerations involved, the technical problem faced by the brainwasher [includes].... how can I get him to speak the speech I wish him to, publicly and apparently voluntarily?...because making such a speech may convince the prisoner himself and so make his future behavior more predictably loyal or consistent with established standards, or because if he speaks or writes the desired words, they may be recorded....and used to affect the behavior of others. $(1957$, p. 48)

The authorities must have spotted Mandela's propensity for going it alone when he wanted to. The task then was to get him to the point of wanting to talk with the government. On the High Organ, Mandela became primus inter pares for the authorities. This observation is consistent with Sparks' view. For example, Sparks believes that

the purpose of the government's talks with Mandela was to explore the possibility of coopting him as leader of... moderates - perhaps along with members of the exiled ANC whom the government's analysts regard as nationalists and moderates, as compared with the communists and other militants. (Sparks, 1994, p. 71; my emphases; but see p. 85 for Thabo Mbeki's role in this outcome)

Indeed, Jimmy Kruger, when he was still minister of justice, had said, "Mandela, we can work with you, but not your colleagues. Be reasonable" (Mandela, 1994, p. 507; my emphases). 
Having firmly established Mandela's leadership and authority, segregation from the flock makes sense, toward nurturing some measure of independence and further differentiations in leadership tactics. According to Sparks, for example,

The decision to send Mandela [to Victor Verster] had been taken by the committee of officials who were meeting with him. "We wanted him to be in a decent place where he could receive people and start playing the political role that we had in mind for him," says Niël Barnard, the National Intelligence Service chief whom Mandela realized was the key figure on the committee. (1994, p. 39)

As Skinner noted in Science and Human Behavior, "in the long run the use of force usually gives way to other techniques which employ genuine processes of behavior. Here the controller need not have power to coerce or restrain behavior directly but may affect it indirectly by altering the environment" (1953, pp. 315316; see also Cohen \& Filipczak, 1989). A taste of the good life therefore appears appropriate; hence, Pollsmoor and Victor Verster. At Pollsmoor, for example, compared to life on Robben Island, the "pleasures" were worlds apart. They included luxuries in rights and facilities (e.g., see Mandela, 1994, p. 501), food with meat and vegetables (p. 502), newspapers and magazines including Time and Guardian Weekly, radio, better visiting areas and better view of visitors-a courtesy not normally shown to visitors by prison staff (p. 503). Indeed, Mandela was allowed the first contact visit, courtesy of W. O. James Gregory, at Pollsmoor, not to mention improved facilities for gardening for Mandela (Mandela, 1994, pp. 504-505).

The authorities also must have had a good sense of the general goals of the ANC and its leadership, for example, as depicted in the Freedom Charter. Mandela observed, for example, that Dr. Niël Barnard of the NIS "had made a study of the ANC" (1994, p. 525), and Coetsee was quoted as having stated that he "had read a lot" about Mandela (Sparks, 1994, p. 24). Note also that, of the initial four issues before the secret committee (Mandela, 1994, pp. 525-527), the one that appeared to have been resolved early (cf. Mandela's list of enduring problem areas for the committee; 1994, p. 535) was nationalization of the economy, an issue raised by the Freedom Charter (see Mandela, 1994, p. 527). The Freedom Charter then would have provided the authorities a window to the general outlines of the outcome to which the ANC leadership aspired, and around which they could tailor their own final outcomes in designing a desirable goal to strive for in molding the ANC leadership in captivity, especially Mandela. For the purposes of implementing some form of shaping program, the Freedom Charter, in conjunction with the confiscated Mandela's manuscripts and other sources, would have aided the authorities in many ways. For example, echoes of the Freedom Charter ring in the words of Wimpie de Klerk, on the Mells secret 
meetings with the exiled ANC: "Look, boys, everything is OK. We can do business with the ANC. They are not that radical. They are willing to negotiate. They are willing to compromise. They see the Afrikaners as an indigenous part of South African population. They are not that dangerous. There's a flexibility even in their economic outlook" (Sparks, 1994, p. 80). The foregoing go a long way to show that in determining the current status of either verbal or nonverbal behaviors to be subjected to shaping at the start of the program as specified by the second pertinent rule of shaping (Galbicka, 1994), these kinds of information would have been very valuable.

By the time they released all the leaders in captivity, talking about negotiations had become firmly established in Mandela's repertoire. In addition, the basic issues of concern to the government had been pursued extensively with him by the presidential working group that the authorities would not have to worry what Mandela did or said thereafter. In the final analysis, the map for the long walk to freedom seems drawn by the apartheid system and the men and women who ran it ${ }^{\mathrm{ix}}$ as Mandela's own accounts indicate that he remained true to the "negotiations" beyond captivity! The convergence of the political ambitions nursed, apparently clandestinely at various points on the journey, by Nelson Mandela and the covert molding, apparently undertaken by the authorities on the ANC leadership and Mandela particularly, more likely than not, produced the political status quo in the South Africa that followed his release. True to the spirit of "reconciliation" (see note 5), Nelson Mandela, the presidential candidate:

I told white audiences that we needed them and did not want them to leave the country. They were South Africans just like ourselves and this was their land too. I would not mince words about the horrors of apartheid, but I said, over and over, that we should forget the past and concentrate on building a better future for all, (1994, p. 606)

evidencing a commitment that was part of the objectives of the government as expressed by Kobie Coetsee noted above. Undoubtedly, Mandela played a significant role in the process.

\section{Mandela's Role in the Shaping Process}

For the purposes of the analysis presented here, it is important to appreciate the dynamic nature of the shaping process. According to Galbicka, "[o]rganisms and environments continuously shape the behavior of other organisms by providing consequences differentially following particular responses demonstrating certain criterion characteristics" (1994, p. 739). Indeed, he points out further, "[t]he contingencies that shape effective shaping are themselves found in the effectiveness of interactions between trainer and client, and will necessarily 
vary with a change in either or both of the individuals" (Galbicka, 1994, p. 740). In the present case, the trainer and the trainee, respectively, sought a common end, perhaps with quite different objectives.

At some point along the way on Mandela's journey, most probably in the later years on Robben Island when prison conditions were considerably relaxed (Part 9), he appears to have decided that he wanted to be chief, prime minister, or president of all the peoples of South Africa. ${ }^{\mathrm{X}}$ His problem then became how he would achieve this, not so much if he would. Moreover, he was in a prime position, as the head of the High Organ of the ANC in prison, to steer the ship toward that goal. For example, Mandela (after meeting with Kobie Coetsee, the minister of justice, in Cape Town in 1986), in his own words:

I told no one of my encounter. I wanted the process to be under way before I informed anyone. Sometimes it is necessary to present one's colleagues with a policy that is already a fait accompli. I knew that once they examined the situation carefully, my colleagues at Pollsmoor and in Lusaka would support me. (Mandela, 1994, p. 519)

When Oliver Tambo in Lusaka did get wind of Mandela's discussions with the government, he demanded to know what they were about, fearing Mandela might be committing "an error in judgement." Mandela:

I replied to Oliver in a very terse letter saying that I was talking to the government about one thing and one thing only: a meeting between the National Executive of the ANC and the South African government. I would not spell out the details, for I could not trust the confidentiality of the communication. I simply said the time had come for such talks and that I would not compromise the organization in any way. (1994, p. 524)

Nelson Mandela was literally imposing, single-handedly, ${ }^{x i}$ the talks on the ANC. The rationale for these automorphic actions is comprehensible only in the wider context of his desires. Before assumption of talks with the government, Mandela wrote:

I chose to tell no one what I was about to do. Not my colleagues upstairs nor those in Lusaka. The ANC is a collective, but the government had made collectivity in this case impossible. I did not have the security or the time to discuss these issues with my organization. I knew that my colleagues upstairs would condemn my proposal, and that would kill my initiative even before it was born. There are times when a leader must move out ahead of the flock, go off in a new direction, confident that he is leading his people the right way. (1994, p. 514; my emphases)

There was neither security nor time to discuss the issues with his own colleagues, but with the very embodiment of the enemy they all stood against. Moreover, he started the talks knowing that his colleagues would object. By moving ahead of the flock, Mandela had resumed the machinations of his own 


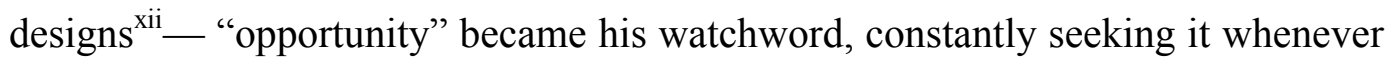
he could find it, but most especially with the Nationalist government of South Africa. ${ }^{\text {xiii }}$

These go to show that Mandela's personal goal was necessary for the shaping process to produce the aftermath of South Africa's apartheid. The interaction of "trainer and trainee" was a necessary condition. Such interaction between authority and subject in a political context has been recognized previously (e.g., Barlow, 1981; Skinner, 1971). As Skinner put it, "[n]o one responds to a prompt, hint or suggestion unless he already has some tendency to behave in a given way. When the contingencies which explain the prevailing tendency are not identified, some part of the behavior can be attributed to the mind" (1971, p. 93). Skinner's allusion to the mind here, of course, gets to the problem of who then is in control (if there is by necessity an interaction between trainer and trainee) and the attending issue of who gets credit or blame for the outcomes.

\section{The Autonomous Man And a Science of Behavior}

According to Skinner, from the proposition that "behavior is shaped and maintained by its consequences" $(1971$, p. 2), two results combine to threaten the notion of autonomous man. First, at the analytical level, increasing complexity in analyses continue to promote contingencies over previous explanatory concepts such as feelings, traits, purposes, intentions, and so on. Second, at the practical level, unlike with genetic endowments that change rather slowly, manipulations of the environment can produce "quick and dramatic effects" (p. 24) on behavior.

Traditionally, the autonomous man is considered a free person "in the sense that his behavior is uncaused" (p. 25). He is responsible thus for what he does and in one sense can be punished for misbehavior whereas in another sense he can receive credit and admiration for his accomplishments. From a behavioral perspective, the problem with the traditional view of the autonomous man is twofold. First, as Skinner pointed out, "a scientific analysis shifts the credit as well as the blame to the environment, and traditional practices can then no longer be justified" (p. 27). Second, he noted further, "by questioning the control exercised by autonomous man and demonstrating the control exercised by the environment, a science of behavior also seems to question dignity and worth" ( $\mathrm{p}$. 26). These problems clearly are manifested in the present analysis, first by the manner in which Mandela is regarded in the aftermath of his release and ascension to the presidency, and second, by the apparent potential to deny him credit for what he has achieved for South Africa. 


\section{Mandela's Saintly AURA}

Upon his release in 1990, Mandela told a throng of well wishers: "I stand here before you not as a prophet but as a humble servant of you the people" ( $p$. 676). Of his separation from Winnie Mandela in April 1992, Mandela wrote: "She married a man who soon left her; that man became a myth; and that myth returned home and proved to be just a man after all" (p. 592). Man or myth, the text of Mandela's autobiography suggests that he acquired a saintly aura, notwithstanding his claim to that throng of well-wishers. Granted the complexity of the content and function of remembering (Ross \& Buehler, 1994) and the intricate properties of the remembering self (Bruner, 1994), there is evidence that autobiographical memory is not necessarily self-serving (e.g., Wagenaar, 1994). Thus, we may not conclude that Mandela's self-aggrandizement is responsible for the portrayal of this aura in his autobiography. The question remains then as to how this saintly disposition that surrounds Mandela's person and life comes about.

\section{According to Skinner,}

We recognize a person's dignity or worth when we give him credit for what he has done. The amount we give is inversely proportional to the conspicuousness of the causes of his behavior. If we do not know why a person acts as he does, we attribute his behavior to him. The goodness to which good behavior is attributed is part of a person's worth or dignity and shows the same inverse relationship to the visibility of control. We attribute the greatest goodness to people who have never behaved badly and hence have never been punished, and who behave well without following rules. Jesus is usually portrayed as such a person. (1971, p. 72)

Clearly, on the aftermath of his release and ascension to the presidency, Mandela was so widely admired, almost to a saintly proportion (e.g., see Meredith, 1997; Sparks, 1994). There continue to be references, even today more than ten years thence, to this saintly ascription ${ }^{\text {xiv }}$ (e.g., Williamson, 2008), although some have began to question it (e.g., Hounshell, 2007; Roberts, 2008; SAPA, 2004). The ascription is in large part because people tend to appraise him on his suffering, endurance, perseverance, and triumph in the face of adversity and injustice. The kind of analysis I have undertaken here, however, would appear to deny him (and others) that very credit and/or admiration. I am thus compelled to note that I have not personally set out to achieve this as a goal. If that is the outcome, however, it derives from the nature of the beast, not from some deliberate effort to deny him and others credit they may deserve. ${ }^{\mathrm{xv}}$ I should note too that it is not always the case that people get credit and/or admiration for their suffering under conditions of incarceration for political reasons. Barlow (1981) presented the case of the Ricketts who were imprisoned by the Chinese in the 
1950s. The Ricketts are noted as saying "We found this a tremendously up-lifting experience, but when we returned home and tried to tell the American people through the press something about our life in prison, many immediately labelled [sic] us 'brainwashed"” (Barlow, 1981, p. 307).

\section{CONCLUSIONS}

As noted in the foregoing, the value of the discovery of the scripts of Mandela's memoirs on Robben Island would have provided valuable information on the ANC leadership in captivity and abroad. Together with other sources of information, it would have enabled the authorities to conduct a systematic, covert work on the ANC leadership in captivity, particularly Mandela. By molding their behavior toward goals that are consistent with and desirable to the authorities, they had set in motion a sequence of events designed ultimately to change the face of South African political life for good. I have argued that this may well have happened, systematically or otherwise, through a shaping process.

I mentioned previously in the introduction that it might be possible to establish that indeed a program was put in place by the South African authorities to change the mind or behavior of their captives. Nevertheless, is an actual program of shaping needed to affirm the validity of the analysis presented here? I think not, for two reasons. First, as noted above, the accounts of other protagonists in the Mandela saga, such as those provided by Sparks (1994) would shed more light on the process that produced the political outcome in South Africa. Of particular interest would be the effects of the countercontrol measures devised by the ANC and the prisoners at various stages of the struggle against the apartheid system on the various actors involved in running it. Secondly, and perhaps more importantly, although shaping in the laboratory often requires an agent, namely the experimenter, shaping in the real world needs no agency to work - the shaping is effected by the interaction of the behaving organism with its physical or social environment, its behavior, and the prevailing (social) contingencies. This is the crux of the idea of selection by consequences (Skinner, 1981). Being retrospective, one could argue that the present analysis has the benefit of 20/20 hindsight. Nevertheless, there is a pattern here too compelling to ignore. This is what led me to explore them in some detail.

Finally, some ethical concerns do arise from this kind of analysis, especially given recent geopolitical developments and treatment of detainees. One could raise the question, for example, whether from the perspective of cultural design such as Skinner (1971) offers, the shaping process, which included the countercontrol measures deployed by Mandela and his colleagues, was ethically good to the extent that it resulted in the survival of the extant South African state. 
The answer depends on what other perspective one brings to it, and such perspectives abound; namely, humanism, Pan-Africanism, nationalism, multiracialism, liberalism, etc., etc. As noted above, for example, the type of conservatism Chinweizu (1994) brings to it would consider what happened in Mandela's case abhorrent and question the "goodness" of the outcome, regardless of how humane it was, compared to alternative methods such as torture in recent news. Another ethical concern is whether this kind of analysis could serve as a primer for oppressive governments to shape the behavior of human rights and other activists. As Skinner aptly noted, talking about behavioral technology, "[s]uch a technology is ethically neutral. It can be used by villain or saint. There is nothing in a methodology which determines the values governing its use" (1971, p. 148). Perhaps a solution would be to inform activists of such tactics and approaches to resisting them. According to Skinner, "[t]he great problem is to arrange effective countercontrol and hence to bring important consequences to bear on the behavior of the controller" (1971, p. 168). The culture at large, in the final analysis, determines what is good for its survival and its values in how it treats those it perceives as some kind of threat, as the apartheid system did. The roles we play as experts or professionals is an integral part of that cultural process, which explains the recent position the APA $(2006,2009)$ has taken on the question of torture of detainees. Perhaps this kind of analysis proffers a different approach in the arsenal of tools available as the debate on alternatives to torture continues.

\section{REFERENCES}

American Psychological Association, APA (2006, August 9). Resolution against torture and other cruel, inhuman, and degrading treatment or punishment. Retrieved February 7, 2009, from http://www.apa.org/governance/resolutions/notortureres.html

American Psychological Association, APA, \& Bray, J. H. (2009, April 22). Saying it again: Psychologists may never participate in torture. Retrieved April 24, 2009, from http://www.apa.org/releases/editorial-bray html

Baer, R., Detrich, R., \& Weninger, J. M. (1988). On the functional role of verbalization in correspondence training procedures. Journal of Applied Behavior Analysis, 21, 345-356.

Barlow, J. A. (1981). Mass line leadership and thought reform in China. American Psychologist, 36, 300-309.

Bauer, R. A., \& Schein, E. H. (Eds.). (1957). Brainwashing [Special issue]. The Journal of Social Issues, 13(3).

Bofelo, M. W. (2008, July 20). Happy birthday saint Mandela, long-live white privilege! Kagablog. Retrieved February 12, 2009, from http://kaganof.com/kagablog/2008/07/20/happy-birthday-saint-mandela-long-live-whiteprivilege/ 
Bruner, J. (1994). The "remembering" self. In U. Neisser \& R. Fivush (Eds.), The remembering self: Construction and accuracy in the self-narrative (pp. 41-54). Cambridge: Cambridge University Press.

Burnstein, D. D., \& Wolff, P. C. (1964). Shaping of three-man teams on a multiple DRL-DRH schedule using collective reinforcement. Journal of the Experimental Analysis of Behavior, 7, 191-197.

Chinweizu. (1994). On negrophobia: Psychoneurotic obstacles to black autonomy. Lagos, Nigeria: Sundoor Publication. [Electronic version]. Retrieved 8 February, 2009, from http://www.africawithin.com/chinweizu/on_negrophobia.htm

Cohen, H. L., \& Filipczak, J. (1989). A new learning environment. Boston, MA: Authors Cooperative. (Originally published 1971)

Ellis, J. (1992). Cohen and Filipczak's A new learning environment: What's new and what's not. Journal of Applied Behavior Analysis, 25, 917-918.

Ericsson, K. A., \& Simon, H. A. (1980). Verbal reports as data. Psychological Review, 87, 215251.

Fairbank, J. K. (1993). Thought reform in China. In N. J. Kressel (Ed.), Political psychology: Classical and contemporary readings (pp. 241-245). New York: Paragon House.

Galbicka, G. (1994). Shaping in the $21^{\text {st }}$ century: Moving percentile schedules into applied settings. Journal of Applied Behavior Analysis, 27, 739-760.

Hermann, M. G. (1986). What is political psychology? In M. G. Hermann (Ed.), Political psychology (pp. 1-10). San Francisco: Jossey-Bass Publishers.

Hounshell, B. (2007, July 18). Nelson Mandela is no saint. Foreign Policy. Retrieved February 15, 2009, from http://blog.foreignpolicy.com/posts/2007/07/18/nelson_mandela_is_no_saint

Mandela, N. R. (1994). Long walk to freedom: The autobiography of Nelson Mandela. London: Little, Brown, \& Co.

Meredith, M. (1997). Nelson Mandela: A biography. New York: St. Martin's Press.

Miller, J. G. (1957). Brainwashing: Present and future. The Journal of Social Issues, 13, 48-55.

Neisser, U. (1982). John Dean's memory: A case study. In U. Neisser (Ed.), Memory observed: Remembering in natural contexts (pp. 139-159). San Francisco: W. H. Freeman \& Co.

Neisser, U. (1994). Self-narratives: True and false. In U. Neisser \& R. Fivush (Eds.), The remembering self: Construction and accuracy in the self-narrative (pp. 1-18). Cambridge: Cambridge University Press.

Neisser, U., \& Fivush, R. (Eds.). (1994). The remembering self: Construction and accuracy in the self-narrative. Cambridge: Cambridge University Press.

Norman-Smith, B. (1976). The republic of Transkei. Johannesburg: Chris van Rensburg Publications.

Roberts, A. (2008, June 26). Nelson Mandela is a hero, but not a saint. Guardian. Retrieved February 9, 2009, from http://www.guardian.co.uk/commentisfree/2008/jun/26/nelsonmandela.zimbabwe

Ross, M., \& Buehler, R. (1994). Creative remembering. In U. Neisser \& R. Fivush (Ed.), The remembering self: Construction and accuracy in the self-narrative (pp. 205-235). Cambridge: Cambridge University Press.

South African Press Association, SAPA. (2004, May 10). Mandela's no saint—UK journo. News24. Retrieved February 9, 2008, from http://www.news24.com/News24/South_Africa/News/0,2-7-1442 $1524790,00 \mathrm{html}$

Skinner, B. F. (1953). Science and human behavior. New York: MacMillan.

Skinner, B. F. (1971). Beyond freedom and dignity. New York: Penguin Books. 
Skinner, B. F. (1974). About behaviorism. New York: Vintage Books.

Skinner, B. F. (1981). Selection by consequences. Science, 213, 501-504.

Sparks, A. (1994). Tomorrow is another country: The inside story of South Africa's negotiated revolution. Sandton, S.A.: Struik Book Distributors.

Wagenaar, W. A. (1994). Is remembering self-serving? In U. Neisser \& R. Fivush (Eds.), The remembering self: Construction and accuracy in the self-narrative (pp. 191-204). Cambridge: Cambridge University Press.

Ward, W. D., \& Stare, S. W. (1990). The role of subject verbalization in generalized correspondence. Journal of Applied Behavior Analysis, 23, 129-136.

Williamson, D. (2008, June 28). Mandela - closest person to a saint in our age of globalization. Western Mail. Retrieved February 9, 2009, from http://www.walesonline.co.uk/news/walesnews/2008/06/28/mandela-closest-person-to-a-saint-in-our-age-of-globalisation-91466$21165404 /$

\section{ENDNOTES}

${ }^{\mathrm{i}}$ This is akin to the considerable interest focused on issues of brainwashing in the psychological literature in the 1950s concerning experiences of American prisoners in China and Korea (e.g., see Bauer \& Schein, 1957; Fairbank, 1993) and attendant thought reform techniques employed.

ii de Waal is not included in Figure 1 because his involvement, from Spark's account, was mostly regarding Winnie Mandela.

iii The account is remarkable in its detail of coverage and content. Mandela is said to have "a personality trait that has astonished many who have met [him] since his release, and that it is his close attention to personal detail, his almost card-index memory for people which enables him to recognize men and women he may not have seen for years or may have met only briefly in a crowd," - a view shared by Nadine Gordimer, the Nobel literature laureate (Sparks, 1994, pp. 46-47).

iv Of those moved to the Pollsmoor prison, Mlangeni was the only nonmember of the High Organ. According to Sparks, “... Govan Mbeki [was] the oldest of the leaders arrested at Rivonia, a lifelong member of the Communist Party, and the leading figure in the radical group. Fellow prisoners on Robben Island recall a particularly sharp exchange in 1968 when Mandela initiated a debate in the Higher Organ on whether the ANC should start thinking about how to open lines of communication with the government. Mbeki was outraged and, say some, retained a lingering suspicion of Mandela's 'moderation' after that." (1994, p. 58). Several points are noteworthy here. First, that Mandela's account, in all its detail and coverage (see note 3) left out the clash with Mbeki over talks (e.g., see Mandela, 1994, p. 428). Second, Govan Mbeki was notably left behind on Robben Island by the authorities when the High Organ was moved to Pollsmoor 
Prison. Finally, in most traditional African cultures, there is a pecking order in leadership grounded in generational seniority. Both the authorities and Mandela must have been keenly aware of this. Yet, on the one hand, the authorities sought to violate it by picking Mandela over Mbeki, not withstanding their ideological differences. On the other hand, any actions taken by Mandela to subvert it would be considered insolent and, in a political context, ambitious by traditional standards (see Norman-Smith, 1976, for a description of the practice in Transkei culture).

${ }^{v}$ Sparks offers insights into the maneuvers surrounding this offer in the inner core of government, and the complications resulting from it for President Botha and his team. Of the offer, Sparks observed,

But Coetsee argued against it. "I had studied the man and I knew he would never accept this," he says. "There was no way Mandela was going to renounce the ANC's armed struggle, for which he had spent all those years in prison" (1994, p. 49). This statement by Coetsee is revealing, for, at that time, he had not met Mandela in person but he knew enough to come to that judgement. Indeed, Coetsee admits, “... I had read a lot about him-all his speeches and all those reports that came across my desk everyday..." (Sparks, 1994, p. 24; my emphases).

In the end, his knowledge of Mandela paid off:

The only benefit to flow from Botha's bungled release offer was that it increased Coetsee's credibility as an adviser... Gradually, Coetsee was able to bring them [Botha and his cabinet] around to accepting a new formula that would get over the difficulty of requiring Mandela to renounce violence. He would be asked to commit himself only to "positive development and reconciliation," without having to renounce anything. Coetsee knew from his discussions with the prisoner that he would agree to this. (Sparks, 1994, p. 51; my emphases)

The discussions, of course, emanated from the secret committee meetings being held with Mandela.

${ }^{v i}$ Sparks suggests that this visit was instigated by the chance meeting on a flight en route Cape Town between Winnie Mandela and Kobie Coetsee (see Sparks, 1994, p. 21). Coetsee was apparently rather impressed by Nelson Mandela at this meeting, their first: "He came across as a man of Old World values... an old Roman citizen with dignitas, gravitas, honestas, simplicitas" (Sparks, 1994, p. 24). It was at this meeting when, Mandela recalled, “... [a]t one point [Coetsee] said to me, 'I am interested in your being put in a situation between prison and freedom.' I asked him whether he meant my whole group of prisoners, and he said no, just me. I was worried about that because it would look as though there was a 
deal, but I didn't say anything about it to him. All I said was, 'Well, your coming here cuts down our problems by 25 percent"' (Sparks, 1994, p. 25; my emphases). Yet, he dissuaded his colleagues from protesting the separation - they were allowed to meet only as dyads rather than in a group!

vii The EPG visit may have been a decisive event in the scheme of things. Of the visit, Sparks wrote: "Coetsee was there at the start of the second meeting but he did not stay, even though Mandela invited him to. 'I wanted him to feel that he was in charge, that he was the host,' Coetsee explains today. 'I was so struck by his presence. It was absolutely remarkable - his alertness, his composure, his bearing, the way he met these people as though he had been a pinstriped leader all his life. That was a crucial impression for me I think that was the day I realized this could be the man"' (Sparks, 1994, p. 33; my emphases) - the chosen one. In effect, the scheme was working.

viii Of the cottage, Mandela wrote: "The cottage did in fact give me the illusion of freedom. I could go to sleep and wake up as I pleased, swim whenever I wanted, eat when I was hungry-all were delicious sensations. Simply to be able to go outside during the day and take a walk when I desired was a moment of private glory" (Mandela, 1994, p. 533; my emphases).

${ }^{\mathrm{ix}}$ According to Sparks, "It was the Broederbond [the Afrikaner secret brotherhood] which had first devised the apartheid ideology and functioned as the primary think tank for shaping government strategy thereafter" (1994, p. 72; my emphases). Others included business people, at home in South Africa and abroad, academics and other professionals, and government operatives at the helms of the affairs of state such as the Coetsees, the Barnards, the Steyns and the Willemses, and so on. These same hands that ran the apartheid machine decided to change the oil, but found that the engine needed an overhaul. Sparks: “...after the later 1970s [the Broederbond's] role began to change as more Afrikaner intellectuals perceived the need for reform [my emphases]. It became the main agency for trying to find a way out of the Afrikaner's historic dilemma: how to abandon apartheid and come to terms with the black majority without losing control of the country [my emphases] and ultimately the national identity of the Afrikaner volk" (1994, p. 72). Sparks reported that P. W. Botha "and his senior ministers... met periodically with the Broederbond executive at a secret mountain retreat called Hawekwa, near the Western Cape Town of Wellington, to discuss ideas on political transformation" (1994, p. 74). See also Figure 1.

${ }^{x}$ At least the authorities, on different occasions, offered Mandela to move to the Transkei, his home province, to retire and, presumably, to resume some political role at the provincial level in his capacity as adviser to the regent. Mandela turned 
down all such offers on the grounds of his opposition to the homeland policy of the apartheid system; for example, see Mandela (1994, pp. 468-469).

xi In Sparks' account, by 1986, at about the time Mandela was seeking talks with the government, the chairman of the Afrikaner Broederbond, Pieter de Lange, met members of the ANC at the Ford Foundation conference in New York. At that conference, he met and "lunched" with Thabo Mbeki, then the Director of Information of the ANC. The ANC in exile was curious and sought contacts of its own both within and around government circles. Sparks described a network of contacts (1994, pp. 76-79) diagrammed in Figure 1. But when time came for government to initiate contacts with them, "Mandela was adamant in refusing to sanction any form of direct contact between the government and the ANC in exile. He remained suspicious of the government's motives, believing they would try to drive a wedge between himself and his colleagues outside the country... [But] without informing Mandela of his intentions, [Niël] Barnard asked Esterhuyse to get in touch with [Thabo] Mbeki and set up a secret meeting with the NIS." (Sparks, 1994, pp. 109-110).

xii Back in May 1961, following the failed stay-at-home campaign, Mandela had proclaimed the end of non-violent struggle to the press. He wrote:

It was a grave declaration, and I knew it. I was criticized by our Executive for making that remark before it was discussed by the organization, but sometimes one must go public with an idea to push a reluctant organization in the direction you want it to go. (Mandela, 1994, p. 258; my emphases)

These were the words of the man who, in another context while damning the newly formed PAC members who in 1959 broke away from the ANC for its nonAfricanist policies embodied in the Freedom Charter, says:

I have always believed that to be a freedom fighter one must suppress many of the personal feelings that make one feel like a separate individual rather than part of a mass movement. One is fighting for the liberation of millions of people, not the glory of one individual. (Mandela, 1994, p. 215)

Well, one cannot ignore what a memento mori does to such a view. Commenting on his goal and desire for "a non-racial, united and democratic South Africa based on one-person one-vote on a common voters' roll" upon his first visit to Soweto when he was released, Mandela wrote: "It was the dream I cherished when I entered prison at the age of forty-four, but I was no longer a young man, I was seventy-one, and I could not afford to waste any time" (1994, p. 560; my emphases).

xiii See, for example, chapters 88-96 in Mandela (1994). 
xiv A Google search for "Nelson Mandela as saint" yielded over a million hits, albeit not all specifically addressing the ascription.

${ }^{x v}$ Others (e.g., Chinweizu, 1994; Bofelo, 2008), by the way, would be vociferously opposed to Mandela and his actions, including his views on multiracialism. For example, according to Chinweizu, "Mandela's liberalism, with its dedication to the primacy of multi-racialism, is all set to subvert the cardinal goal of returning to the black aborigines of South Africa all the land stolen from them by the white invader-settlers." 